European Journal of Sustainable Development Research

2019, 3(4), em0102

ISSN: $2542-4742$

\title{
Effects of Change in Land Use Activities and Land Cover on Ragati River
}

\author{
Anne Njeri Mwangi ${ }^{1 *}$, Shadrack K Murimi ${ }^{1}$, George L. Makokha ${ }^{1}$ \\ ${ }^{1}$ Kenyatta University, KENYA \\ *Corresponding Author: ragatiannmwangi@outlook.com \\ Citation: Mwangi, A. N., Murimi, S. K. and Makokha, G. L. (2019). Effects of Change in Land Use \\ Activities and Land Cover on Ragati River. European Journal of Sustainable Development Research, 3(4), em0102. \\ https://doi.org/10.29333/ejosdr/5947
}

Published: September 29, 2019

\begin{abstract}
Changes in land-use and land-cover have negatively affected the hydrology of Ragati River. It is one of the many rivers in Kenya that are considered as hot spots due to over abstraction especially during the dry season. This study aimed at evaluating the effects of land use and land cover changes which are important in ensuring sustainable use of the water resource. This study aimed at achieving the following objective: i) To analyze land use activities and land cover changes within Ragati River catchment area from 1990 to 2010; ii) To analyze the discharge of Ragati River during low flow and high flow seasons; iii) To assess the response of the sub-catchment to land-use and land cover change; iv) To evaluate the measures taken to mitigate negative effects of land use and land cover changes on the Ragati catchment. Satellite data was integrated in GIS to examine the extent of land-use and cover change in the sub-catchment. Both quantitative and qualitative data were used in this study. Various data types such as socio-economic data, land-use data, rainfall data and river flow data were collected in order to supplement information from landsat images. Analysis was done using classified landsat images of 1990, 2000 and 2009. SPSS and Ms Excel were used to analyse descriptive data. This study revealed that between 1988 and 2000 the dense forest decreased by 15\%, land under perennial crops increased by $4.26 \%$, cropland increased by $11 \%$, settlement increased by $45.30 \%$ while closed woodland decreased by 4.6\%. The results also show some change between 2000 and 2009. This can be attributed to increased campaign on reforestation of Mt. Kenya forest. Land under perennial crops decreased by $57 \%$, crop land further by $4.04 \%$, settlement increased by $49.41 \%$ while closed woodland decreased further by $3 \%$. Over abstraction of water and river bank encroachment are some of the causes of changes in the volume of water flowing in the river. This study recommends that water users should be made aware of the importance of sustainable use of the water resource.
\end{abstract}

Keywords: land use, river land use, river hydrology

\section{INTRODUCTION}

Human activities are exerting too much pressure on fresh water resource and if this this trend is left unchecked, water resources whose demand is ever increasing will be depleted. Since the demand is higher than the supply, water scarcity has become a problem globally (Cosgrove and Rijsberman, 2000; Taha, 2007). Water scarcity is likely to increase in the coming years if awareness on sustainable water resource management is not created (Ayenew, 2007). Fresh water is used in activities such as domestic (drinking, cooking, washing and subsistence farming), industrial (Power generation, waste disposal treatment), agricultural (large scale commercial farming) and of leisure activities (kayacking, swimming). Water is an important resource for social and economic development. It is also important for maintaining a healthy ecosystem. As economic development increases to cater for the increasing world's populations more allocations of water for the domestic, agriculture and industrial are needed (UN-Water, 
2007). This has led to increased demand for fresh water which in return leads to increased abstraction of water from fresh water sources such as rivers.

Water resource is a basic need and also important in development and in reducing poverty (Förch and Thiemann, 2004). Water is one of the major current issues facing Africa. There is unequal geographical distribution and accessibility of water supplies from lakes, rivers and rainfall. Climate change can also cause pressure on water availability and accessibility. This is likely to be followed by an increase in water for irrigation to feed the extra number of people and water for generating power for the developing economies. There will be an increase in competition for water by the different water needs coupled with pollution. Ragati River has uncontrolled abstraction of water despite efforts by WRMA to allocate water through the system of permits and to enforce these permits (WRMA 2012). This study aimed at establishing how land use activities and land cover affect hydrology of Ragati River.

Malaki (2017) noted that the greatest impact of change in land use is the loss of bio-diversity in the region concerned. Transformations in the land use affects the environmental functioning in the short-term as well as in the long term. Malaki noted that destruction of the bio-diversity in the greatest challenge to changes in land use particularly when urbanization takes place. Erosion and land degradation are greatly manifested when urbanisation takes place as concrete jungle takes the place of vegetation and bio-diversity. This affects the sustainable development of the region particularly where no environmental assessments take place before changes in land use occur. The flora and fauna are permanently lost as well as other adverse effects that are resultant to changes in land use.

Bronstert, Hiehoff, and Burger (2012) noted that there was a growing concern on the recent urbanization in African states since it encompasses changes in the hydrological aspects of the region. With water shortage hitting most regions in Africa, there is need to analyse the changes in land use and resultant impact on hydrological elements. Water is a diminishing assets and thus when land use changes, the resultant effect on the hydrological states needs further analysis. The loss of vegetation and replacement with concrete building, the region which is greatly regarded as an important water tower in Mt Kenya region requires analysis. It is important to note that no single study has been carried out in the area to analyse the effect of land use activities on the land cover. Much of studies have concentrated on larger towns such as Thika, Naivasha among others. However, it is evident that changes in land use activities needs to be tempered to allow for mitigation to avoid loss of bio-diversity in many regions in Kenya.

\section{RESEARCH DESIGN AND METHODOLOGY}

\section{Research Design}

This study employed experimental design. This research design was chosen because the research involved measurement of river discharge and calculation of land cover changes in the catchment.

\section{Sampling Procedure}

The study adopted a stratified simple random sampling to select households in Ragati catchment. The sample size of the study was based on the total number of households in the catchment and was calculated using Yamane (1967) formula (1). The area has about 35217 households. This formula is best placed for qualitative studies like for the case of this study.

where:

$$
n=\frac{N}{1+N(e)^{2}}
$$

$\eta$ is the sample size

$\mathrm{N}$ is the total number of people in the catchment

$e$ is the level of precision and/or margin of error set at $10 \%$.

\section{Study Area}

River Ragati is $55 \mathrm{~km}$ long and covers a region that fall within parts of Kirinyaga and Nyeri counties, Kenya. It found on the upper Tana catchment. It covers an area of about $250 \mathrm{~km}^{2}$. Ragati River originates from South West of Mt. Kenya forest. This part of the forest is called Ragati forest. It is found between 1800- $2500 \mathrm{~m}$ ASL. Its watershed lies between longitudes $37^{\circ} 06^{\prime} \mathrm{E}$ and $37^{\circ} 20^{\prime} \mathrm{E}$ and latitudes $0^{\circ} 20^{\prime} \mathrm{S}$ and $0^{\circ} 40^{\prime} \mathrm{S}$. The total population in the catchment as at 2013 is 290, 428 persons. The source of the river is in Nyeri county while the mouth is in Kirinyaga county. The area has a river gauging station known as 4BB01 found at the confluence of Ragati River and Tana River in Sagana. The location of the river gauging station is latitude 


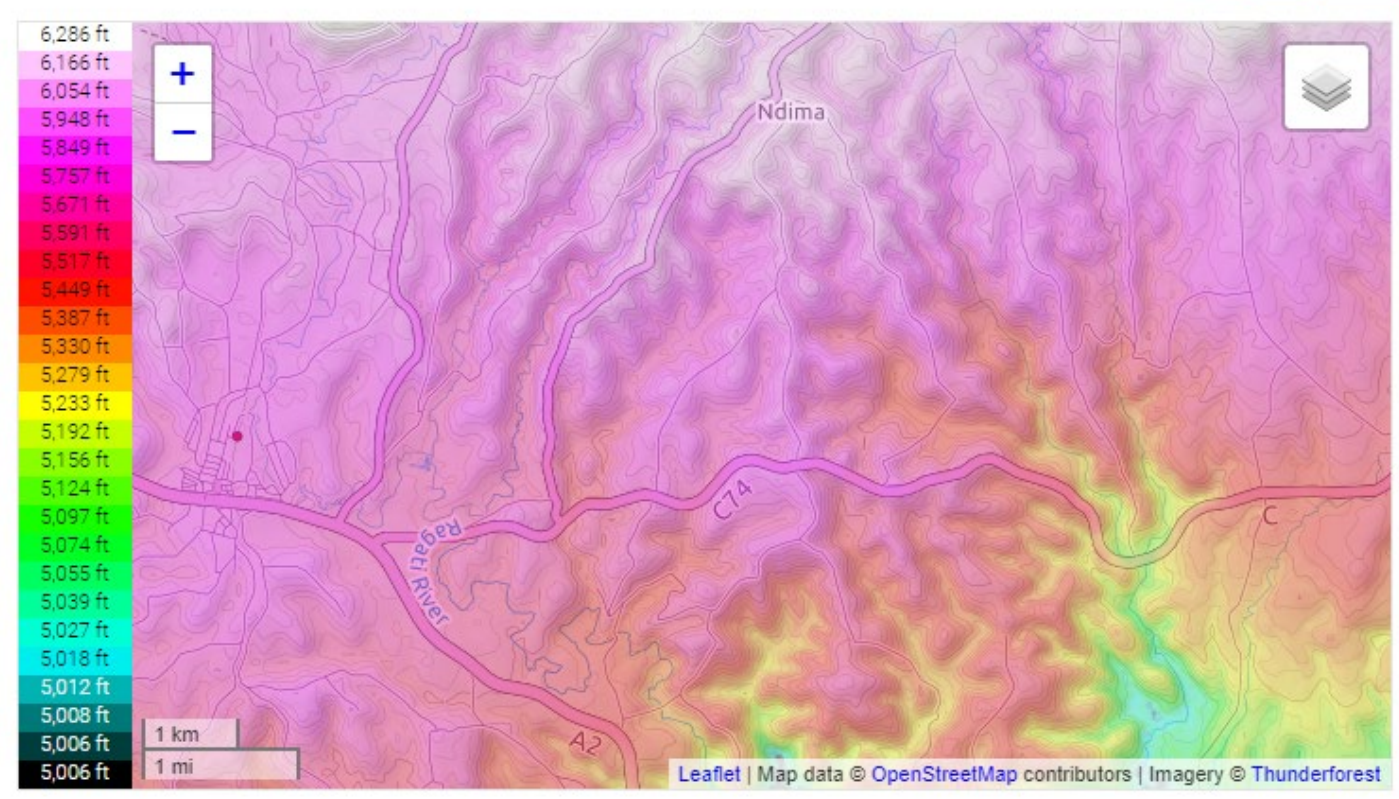

Figure 1. Topographical Map of Ragati River

$0^{\circ} 01^{\prime} \mathrm{S}$ and longitude $37^{\circ} 19^{\prime} \mathrm{E}$. The area has the following agro ecological zones: the upper highland zone that is made up of forest reserve and lower highland zone that is made up of tea zone, coffee zone and maize zone. The main land use activities in the area include agriculture, deforestation and settlement. This catchment has been chosen for this study because of its economic importance in the region (Figure 1 shows Topographical Map of Ragati River).

\section{Data Collection Procedure}

The study used stratified sampling where the area was stratified into three zones (upper, middle, lower) guided by agro-ecological zones. These zones include the upper highland zone that is made up of forest reserve and lower highland zone that is made up of tea zone, coffee zone and maize zone. Primary data on land use activities in the area were identified by use of field observations through transect walking. Observations through transect walks were made along the river on each zone for the identification of surface features and land-use types. Landsat images on land use activities and land cover for years 1988, 2000, 2009.

\section{Data Analysis}

The landsat images collected were analysed by stacking different images representing different bands. Landsat image for the year 1988 had 7 bands while that of the years 2000 and 2010 had 8 bands. The colour composites used for classification were ultra blue for band 1 , blue for band 2 , green for band 3 , red for band 4 , near infrared for band 5 , shortwave infrared 1 for band 6 , shortwave infrared 2 for band 7 , panchromatic for band 8 . This process was done using ERDAS imagine software. Land use and land cover classification followed. It was done by first identifying the signatures that represent the different land cover categories. The categories were identified by sorting the pixels of the images into classes based on their signatures and classification decision rule. The decision rule is a mathematical algorithm that uses data contained in the signatures and performs the actual sorting of pixels into distinct class values (Coppin and Bauer 1996). The percentage change for land use and land cover change was done by use of formula (2) (Renny 2012).

$$
\% \text { Change }=\frac{\text { observed } \text { change }}{\text { Sum of Area }} \times 100
$$

Descriptive data that was collected through field observation, questionnaires and interviews was analysed using chart, maps, tables and photograph.

\section{RESULTS AND DISCUSSION}

\section{Land Use and Land Cover Changes}

From the ground truth data obtained during fieldwork and classified land sat images of 1990, 2000 and 2009; the sub-catchment has undergone various land-use and land cover changes. The data collected from field observation and land sat images for the years 1988, 2000 and 2009 show that land use and land cover has 
Table 1. Land-use and land-cover change between the years 1988 and 2009

\begin{tabular}{|c|c|c|c|c|c|c|}
\hline \multirow{2}{*}{ CATEGORIES } & \multicolumn{2}{|c|}{1988} & \multicolumn{2}{|c|}{2000} & \multicolumn{2}{|c|}{2009} \\
\hline & Area $\left(\mathrm{km}^{2}\right)$ & $\%$ & Area $\left(\mathrm{km}^{2}\right)$ & $\%$ & Area $\left(\mathrm{km}^{2}\right)$ & $\%$ \\
\hline Dense forest & 63.04 & 26 & 53.47 & 22 & 59.1 & 25 \\
\hline Perennial cropland & 18.51 & 8 & 19.3 & 8 & 8.18 & 3.4 \\
\hline Annual cropland & 112.54 & 47 & 123.86 & 52 & 130.13 & 54 \\
\hline Settlement & 1.17 & 0.49 & 1.7 & 0.7 & 1.84 & 0.8 \\
\hline Closed woodland & 45 & 19 & 41.93 & 17 & 41.52 & 17 \\
\hline TOTAL & 240.26 & & 240.26 & & 240.77 & \\
\hline
\end{tabular}

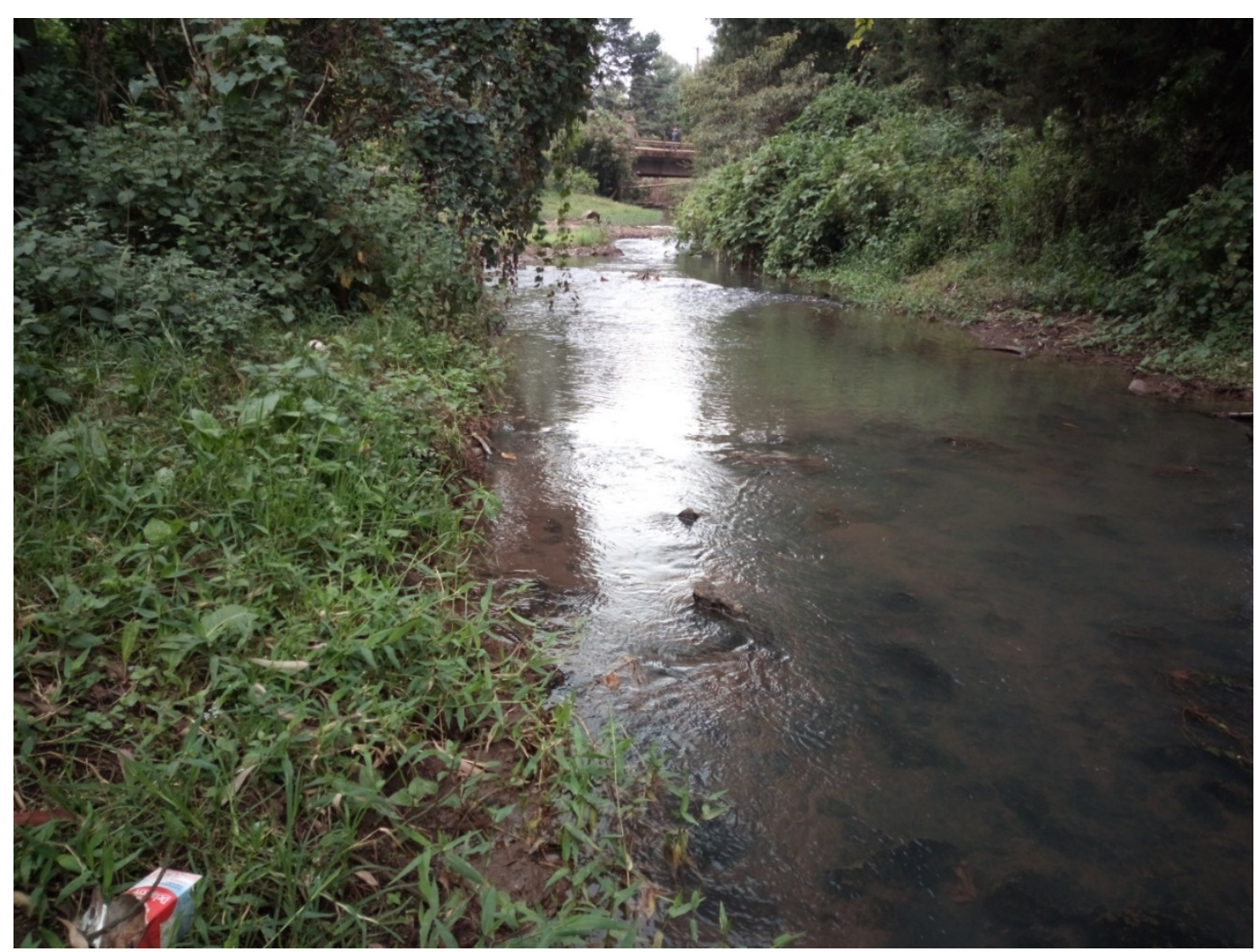

Figure 2. Ragati River in the Outskirts of Karatina Town (KCB Hospital Bridge at the background)

significantly changed in the sub-catchment. The results in Table 1 show that there is land use and land cover change between the year 1988, 2000 and 2009. In 1988 the area under dense forest was 26\% then decreased to $22 \%$ in the year 2000. The area under perennial crops was $08 \%$ in 1988 and 2000 . Annual cropland was 47\% in 1988 and increased to $52 \%$ in the year 2000. Settlement increase from $0.49 \%$ in 1988 to $0.7 \%$ in year 2000.Closed woodland was $19 \%$ in 1988 but it decreased to $17 \%$ in year 2000. These results are shown in Table 1.

There has been a significant land-use/cover change in the sub-catchment where the dense forest was $26 \%$ in 1988 then decreased to $22 \%$ in 2000 . This can be attributed to increased deforestation that was rampant as people sought to create more agricultural land. This however changed by the year 2009 as the percentage of dense forest increased to $25 \%$ in the year 2009. This may be due to increased afforestation and reforestation by the forestry department in the region. Perennial cropland was $08 \%$ in the years 1988 and 2000 . It decreased to $3.4 \%$ in the year 2009. This can be attributed to people clearing land for settlement. The cropland was $47 \%$ in the year $1988 . \mathrm{It}$ increased to $52 \%$ in the year 2000 and $54 \%$ in the year 2009. This may be due to increasing demand for food by the increasing population in the sub-catchment. Settlement was $0.49 \%$ in the year 1988 .It increased to $0.7 \%$ in the year 2000 and $0.8 \%$ in the year 2009. This increase may be due increasing building of residential, business houses and building houses for social amenities such as schools, hospitals and churches to cater for the needs of the increasing population. The closed woodland was $19 \%$ in the year 1988 . It decreased to $17 \%$ in the years 2000 and 2009. (Figures 2-4 shows the River width as well as effect of land use on River Ragati Overflow zones). This decrease may be due to people clearing land to create more agricultural land and land for settlement. According to classified landsat images for 1988, 2000 and 2009 upstream tend to be more forested, have closed woodland and covered with perennial crops. There is also less cropland and settlement. These results also show that the downstream is characterized with more cropland and settlement than the upstream. There are also very small areas covered by closed woodland and forest cover. 


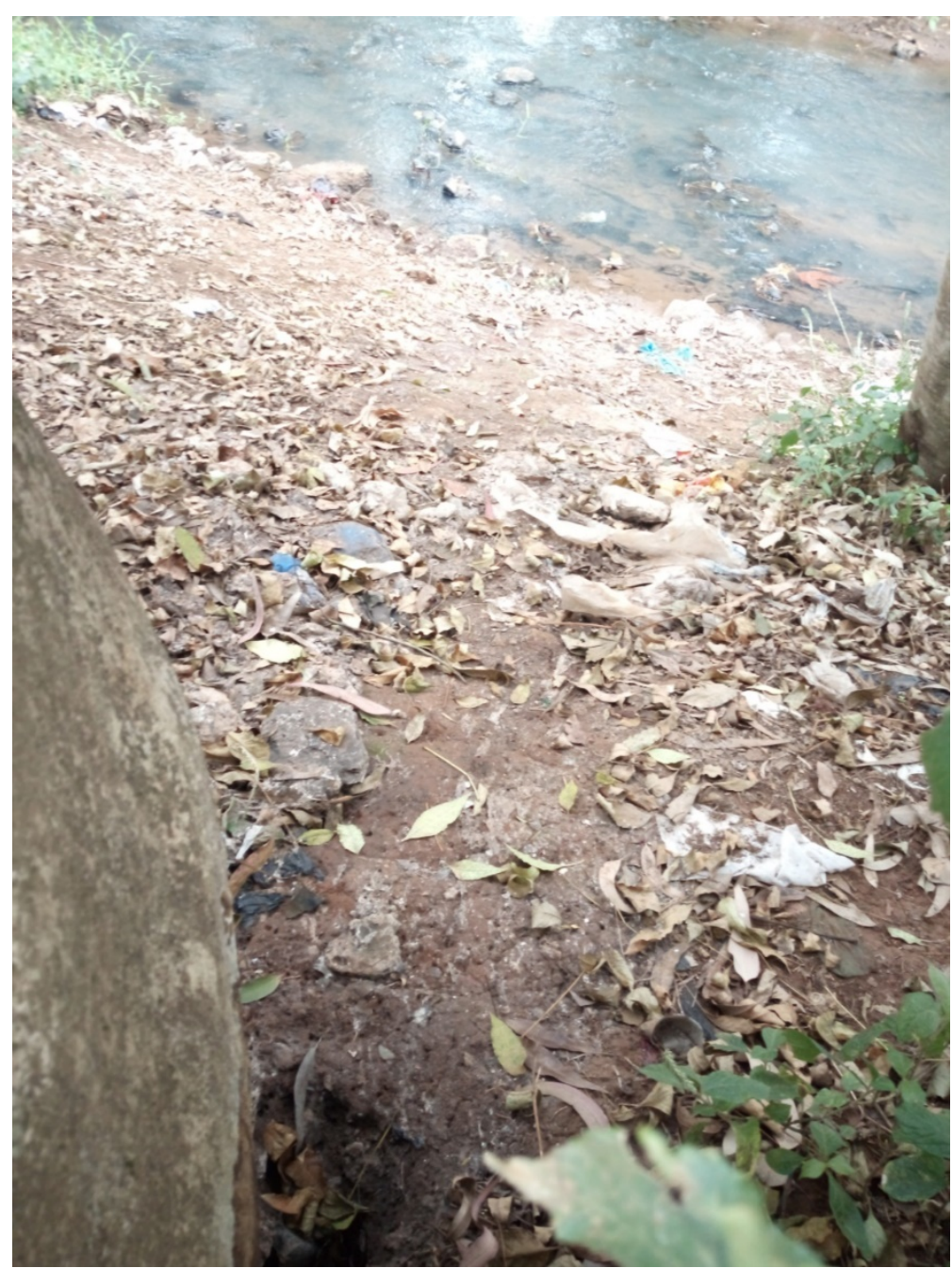

Figure 3. Seware Drainage just next to Ragati River (Next to Highway A2 Governemnt Public Works Offices Karatina Town)

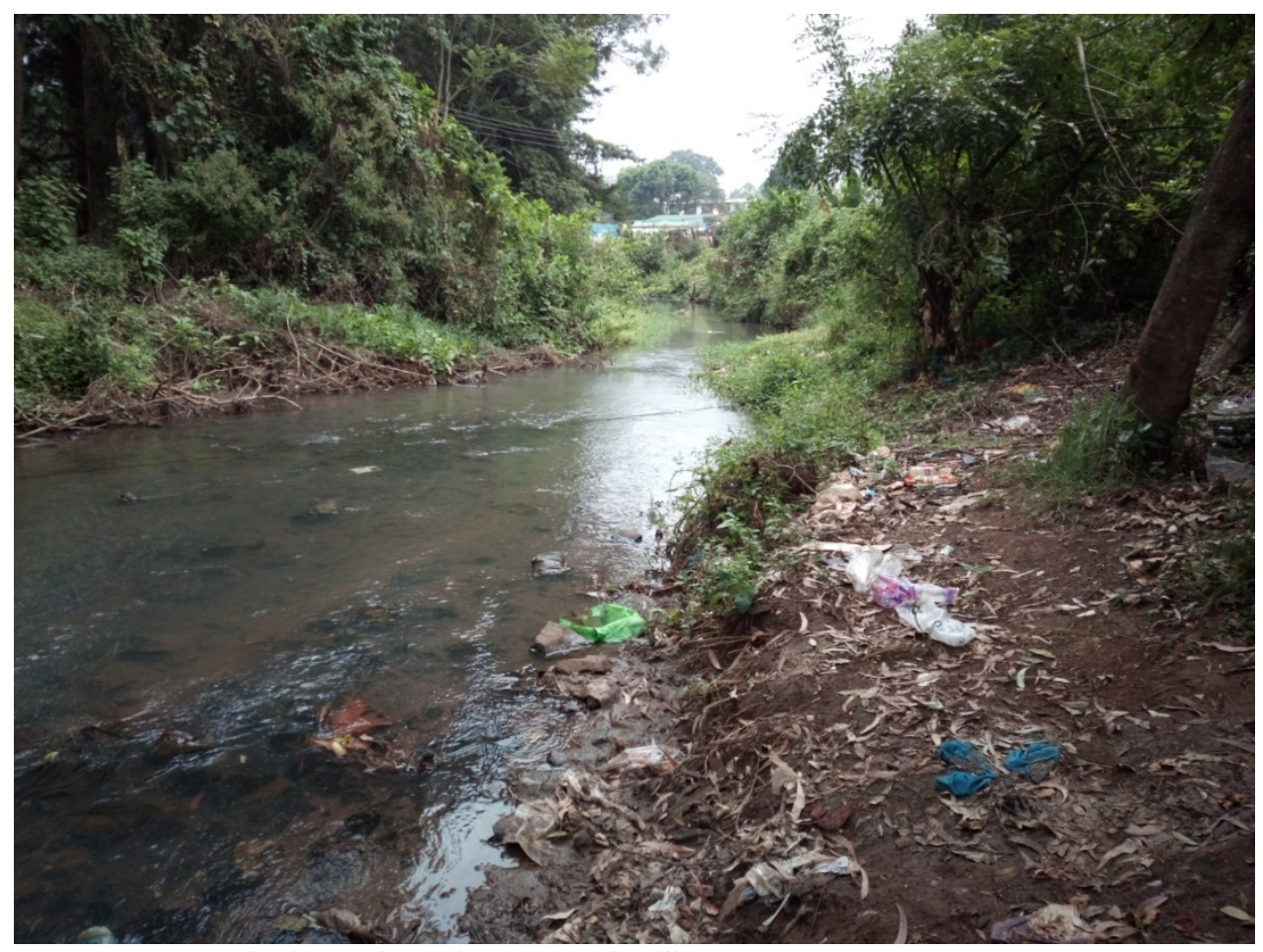

Figure 4. Ragati River Flow along Ragati Village 
The study also established that previously, the residents of KIamwangi Villages used to dig up to 30 feet and access underground water. The water wells dug in the 1980s and 1990s have since dried up. However currently analysis of most water wells ranges from 0ver 80 feet to access underground water.

\section{Effects of Land use and Land Cover Changes on River Flow}

High flows and low flows of a river are normally affected by changes in land use and land cover. This study has shown that during the rainy season the volume of river flow increases. This may be due to increased surface run off and reduced storage in the sub-catchment. The annual flow volumes change from time to time depending on rainfall amounts, water use patterns and evaporation rates. Ragati River experiences unequal distribution of flows within the year. The study also revealed that the annual volumes in the river are higher during the long rains and during short rains there are relatively small volumes of flow. The high flows experienced during the rainy season and the low flow volumes during the dry seasons show that the annual flows over the years have been determined by changes in the amounts of rainfall during the two rain seasons. These changes in flow can also be caused by are depletion of vegetation cover in the sub-catchment which reduced capacity of the sub-catchment to store moisture. Water resources and stream flow are largely affected by land use. Such land use activities include change in forest cover, cropland, pasture and urban land use.

Urban areas have many impervious surfaces which increase the surface run-off and affect the hydrologic response. In urban areas a large proportion of precipitation is converted to surface run-off. River in such areas have faster hydrological responses, decreased lag time, increased peak flow, reduced base flow and low flow, decreased water quality from increased surface run off and effluent discharge (Chang, 2007; Doughtery et al., 2007).

\section{Conclusion}

It is important to understand how land use and land cover changes influence the sub catchment hydrology. This will inform formulation of policies that will minimize the negative effects of future land use and land cover changes. Some of land use and land cover changes noted by this study are increase in impervious surfaces which decrease infiltration rate and increase run off hence causing low base flow during the dry seasons. It is evident that the sub-catchment hydrology is currently under pressure following the rapid land-use change which is taking place in Ragati River.

The study revealed that that the major land use and land cover change in the sub- catchment is agriculture and increase in built up areas. These changes have had negative effects on the flow regime and recharge of Ragati River with increased demand for water and on food security. The results also revealed that more land-use and land cover changes are likely to take place as more land is converted over time especially forest land to agricultural land, and agricultural land to settlements, which threatens the existence of water sources in the future.

\section{Recommendations}

* Enhance enforcement of passed policies relating to regulating the use of water from the river especially during the dry season. The National Environmental Management Authority should act on institutions and people breaking the Law as evidenced by the photographs.

* Enhance knowledge effects of land use and land cover on river discharge and why mitigation measures are necessary for sustainable use of water resources. There should also be a follow up to ensure water conservation is being observed. Community liaison and environmental based organisations should be enhanced to educate people on the need for environmental conservation.

* Land use and land cover changes are such as agricultural activities, settlements are inevitable because the demand for food, shelter and rising living standards of the increasing population must be met. It is therefore important to increase tree cover in the watershed by increasing tree cover in residential areas and along the road sides.

* Water user management groups should work together to enhance management of the water resource. They should also work together with locals to come up with other economic activities that will reduce over reliance on Ragati River especially during the dry season.

\section{REFERENCES}

Ayenew, T. (2007). Water management problems in the Ethiopian rift: Challenges for development. Journal of African Earth Sciences, 48, 222-236. https:// doi.org/10.1016/j.jafrearsci.2006.05.010

Bronstert, A., Hiehoff, D. and Burger, G. (2012). Effect of climate change on land use change on storm run off generation. Hydrological Process, 16(1), 45-59. https://doi.org/10.1002/hyp.326

Chang, H. (2007). Comparative Stream/low Characteristics in Urbanizing Basins in the Portland Metropolitan Area, Oregon, USA. Hydrological Processes, 21, 211-222. https:// doi.org/10.1002/hyp.6233 
Coppin, P. and Bauer, M. (1996). Digital Change Detection in Forest Ecosystems with Remote Sensing Imagery. Remote Sens. Rev., 13, 207-234. https://doi.org/10.1080/02757259609532305

Cosgrove, W. and Rijsberman, F. (2000). World water vision: Making water everyone's business. London: World water council, Earthscan.

Dougherty, M., Dymond, R. L., Godrej, A. N., Grizzard, T. J., Randolp, J. and Ziper, C. E. (2007). Quantifying Lon-Term Hydrologic Response in an Urbanizing Basin. Journal of Hydrologic Engineering, 12, 33-42. https://doi.org/10.1061/(ASCE)1084-0699(2007)12:1(33)

Förc Forch, G. and Thiemann, S. (2004). Lake Abaya Research Symposium Proceedings. Catchment and Lake.

Malaika, P. A. (2017). Effects of change in land use activities and land cover (Unpublished master thesis). University of Nairobi.

Taha, F. (2007). Water Scarcity Leading to International Conflict: The Case of the Nile Basin. Department of History, Faculty of Arts, University of Khartoum, Guest i Researcher Nile Basin Research Program, University of Bergen JanJune 2007.

UN-Water. (2007). Coping with water scarcity: Challenge of the twenty-first Century. World Water Day, 22nd March, 2007.

WRMA. (2012). Water abstraction and pollution survey of River Ragati and Thiba, WRMA, Embu.

Yamane, T. (1967). Statistics, An Introductory Analysis (2nd Ed.), New York: Harper and Rows. 